DOI 10.37882/2223-2982.2021.10.29

\title{
СМОЛЕНСКИЕ СВЯЩЕННОСЛУЖИТЕЛИ - ТРУЖЕНИКИ ТЫЛА ВЕЛИКОЙ ОТЕЧЕСТВЕННОЙ ВОЙНЫ
}

\section{SMOLENSK CLERGY - HOME FRONT WORKERS OF THE GREAT PATRIOTIC WAR}

S. Semenov

Summary: The article considers the history of patriotic activity of Smolensk clergy-home front workers of the Great Patriotic War, their role in organizing the collection of material resources in support of the Red Army, as well as the practice of awarding them with medals "For valiant labor in the Great Patriotic War of 1941-1945".

The author has set a goal - on the basis of regional documents to identify clergy-home front workers; to restore the history of their life and participation in the Great Patriotic War; to analyze the practice of recognizing them as home front workers.

The source base consisted mainly of documents from the State Archive of the Smolensk Region (the Smolensk Regional Executive Committee fund), materials on the history of the Smolensk Diocese of the Russian Orthodox Church during the Great Patriotic War. The documents on awarding and awarding medals, official documents, correspondence on awarding issues were studied.

The role of Smolensk clergy in achieving Victory is shown, the circle of representatives of the clergy of the Russian Orthodox Church who were recognized as home front workers by awarding medals after the war, as well as those who only presented themselves, but did not receive awards, is studied.

The author believes that the Smolensk clergy made a considerable contribution to the development of patriotic activity in the conditions of the war-ravaged region, and, given the attitude of the Soviet state to the church, they are one of the most unique groups of home front workers in their total mass.

It is concluded that the fact that the Smolensk clergy are recognized as home front workers is the most vivid reflection of the recognition by the Soviet authorities of the patriotic activity of the church, its unwillingness to alienate itself from the people in the midst of a difficult war.

Keywords: home front workers, clergy, the Great Patriotic War, clergy, the Russian Orthodox Church, Soviet awards.

\author{
Семенов Сергей Евгеньевич \\ Аспирант, ФГБОУ ВО «Смоленский государственный \\ университет» \\ alarm-xxx@yandex.ru
}

Аннотация: В представленной статье рассматривается история патриотической деятельности смоленских священнослужителей - тружеников тыла Великой Отечественной войны, их роль в организации сбора материальных средств в поддержку Красной Армии, а также практика награждения их медалями «За доблестный труд в Великой Отечественной войне 1941-1945 гг.» Автором поставлена цель - на основе региональных документов выявить священнослужителей - тружеников тыла; восстановить историю их жизни и участия в Великой Отечественной войне; проанализировать практику признания их тружениками тыла.

Источниковую базу составили в основной своей массе документы Государственного архива Смоленской области (фонд Смоленского облисполкома), материалы по истории Смоленской епархии Русской Православной Церкви в годы Великой Отечественной войны. Исследованы документы по награждениям и вручениям медалей, служебные документы, переписка по вопросам награждения.

Показана роль смоленских священнослужителей в достижении Победы, исследован круг представителей духовенства Русской Православной Церкви, признанных по итогам войны тружениками тыла путём награждения медалями, а также тех, кто только представлялся, но не получил награды.

Автор считает, что смоленские священнослужители внесли немалый вклад в развитие патриотической деятельности в условиях разорённого войной региона, и, учитывая отношение Советского государства к церкви, являются одной из наиболее уникальных групп тружеников тыла в общей их массе. Сделан вывод, что факт признания смоленских священнослужителей тружениками тыла является наиболее ярким отражением признания со стороны Советской власти патриотической деятельности церкви, её нежелание отчуждаться от народа в разгар труднейшей войны.

Ключевые слова: труженики тыла, священнослужители, Великая Отечественная война, духовенство, Русская Православная Церковь, советские награды. стория духовенства в первые десятилетия Советской власти - это длинный крутой вираж в отношениях между церковью и государством. С самого прихода к власти большевиков церковь подвергалась гонениям: храмы закрывались и разорялись, священников репрессировали, церковное имущество национализировалось. Четверть века такого давления привела некогда один из важнейших институтов общественной жизни в печальное состояние. И, тем не менее, когда началась Великая Отечественная война, церковь активизи- ровала общественную деятельность в пользу своей, несмотря ни на что, родной страны. Не осталось в стороне и смоленское духовенство, которое в это тяжёлое время не пожелало уходить в изоляцию, а наоборот, сумело наконец наладить диалог и сотрудничество с властью.

Священнослужители брали шефство над детьми погибших на фронте воинов, поддерживали деньгами и продовольствием, собранным среди паствы, детские дома. В январе 1944 года, когда И.В. Сталин дал согласие 
на открытие в Госбанке СССР специального счёта для внесения пожертвований на нужды обороны страны Русской Православной Церковью, смоленское духовенство тут же включилось в этот патриотический почин. К сожалению, уже вскоре власть превратила лучшие движения души верующих практически в обязанность церкви, взяв процесс сбора пожертвований под жёсткий контроль - уполномоченный по делам религиозных культов постоянно требовал усиления интенсивности работы и строгого предоставления отчётности. Дошло до того, что денежные средства в Фонды обороны и Красной Армии вносились церковью анонимно [1, с. 133-153].

При этом организовывать сборы на разорённой войной Смоленщине, где люди сами жили впроголодь, было очень трудно. Власти, демонстрируя на словах поддержку патриотической деятельности, по факту продолжали препятствовать открытию новых церквей (за весь период 1944-1945 годов не было открыто ни одной новой церкви, хотя жители различных населённых пунктов много раз обращались в исполкомы с просьбой разрешить деятельность прихода), а действовавшие обкладывали драконовскими налогами и множеством ограничений на ведение миссионерской деятельности.

Тем не менее, активная общественная деятельность священнослужителей и их немалый вклад в достижение Победы не могли быть не отмеченными властью, которая сама же в годы войны демонстрировала свою поддержку благим начинаниям церкви. Целый ряд священнослужителей был отмечен государственными наградами Советского Союза, некоторые даже орденами. И, конечно, учреждая медаль «За доблестный труд в Великой Отечественной войне 1941-1945 гг.» спустя месяц после окончания боевых действий, государство довольно широко определило круг лиц, которым могла быть она вручена. Поэтому, пусть и не сразу, но ряд священников стали кавалерами этой медали - отличительной награды труженика тыла Великой Отечественной войны, по-своему уникального в мировой истории знака отличия.

7 марта 1947 года председатель Смоленского облисполкома А.Н. Кидин и секретарь облисполкома В.В. Луппов подписали по-своему уникальное в наградной практике в отношении жителей Смоленщины Решение № 464 «О вручении медалей «За доблестный труд в Великой Отечественной войне 1941-1945 гг.» служителям церкви». В соответствии с Указом Президиума Верховного Совета СССР от 6 июня 1945 года и Положением о медали «За доблестный труд в Великой Отечественной войне 1941-1945 гг.», за проявленную патриотическую деятельность в годы войны облисполком постановил вручить наградыпятислужителямРусскойПравославнойЦеркви[11, л. 86].

Переписка между епархией и облисполкомом даёт представление, за какие именно заслуги пятеро священников в атеистическом по своей сути государстве удостоились такого отличия. Первоначальные кандидатуры для награждения отбирал управляющий Смоленской епархией, епископ Смоленский и Дорогобужский Сергий (Смирнов). Таковых оказалось семеро, и хотелось бы остановиться на фактах их совсем не простых биографий, которые удалось установить в ходе исследовательской работы.

Занимавший в первые послевоенные годы пост благочинного Вяземского округа протоиерей Михаил Петрович Соколов родился в 1874 году. В годы немецкой оккупации Вязьмы он был священником в Вяземском Свято-Троицком соборе и одновременно в церкви Троицы Живоначальной села Федяева. Отмечалось, что Соколов представлял собой «тип передового священника», являющегося «не только формальным исполнителем распоряжений Епархиального Архиерея, но в его лице преломляется сознание полной лояльности и выразителя высокого долга в дни Отечественной войны». Патриотические сборы денежных средств для нужд восстановления народного хозяйства за 1945-1946 годы составилипоСвято-Троицкомухраму 99782 руб.,аповсему округу - 343852 руб[11, л. 88].

Самый пожилой из представлявшихся Епископом к награде - благочинный Рославльского округа протоиерей Всеволод Михайлович Корицкий - родился в 1864 году. В годы гитлеровской оккупации он являлся священником Вознесенского храма в Рославле. Через свою паству он собирал для советских военнопленных - узников лагеря Dulag-130 - продовольствие, спасая их от голодной смерти, а некоторых даже сумел вызволить под личное поручительство. Когда осенью 1943 года пришла Красная Армия, отец Всеволод вошёл в состав комиссии по расследованию злодеяний немецко-фашистских захватчиков в Рославльском районе. Как и остальные священнослужители, он активно занимался сборами денежных средств на восстановление разрушенного войной хозяйства. Ежемесячно он собирал по 500-700 руб., а по округу годовой сбор доходил до 100000 руб. Вплоть до глубокой старости отец Всеволод продолжал работать в Вознесенской церкви. Лишь за год до своей кончины, в 1953 году, он оставил службу и ушёл на заслуженный отдых [6]. К сожалению, всех его заслуг с точки зрения властей не хватило, чтобы отметить их медалью по итогам войны.

Третьим кандидатом на получение медали «За доблестный труд в Великой Отечественной войне 19411945 гг.» был отобран благочинный Смоленского округа, священник церкви Святого Пророка Божия Илии в селе Шестакове Кардымовского района Николай Иванович Валюженич, 1891 года рождения. Его представление несколько отличается от остальных - там не имеется сведе- 
ний о месячных и годовых сборах его прихода и округа, зато отмечается ответственный подход к выполнению архиерейского задания объездить все, даже самые отдалённые точки округа, с целью оценки патриотической работы духовенства на местах. В документе отмечалось: «Из донесений его видна серьёзность, деловитость и настойчивость в подходе... Это его исключительные заслуги, которые дали реальные результаты» [11, л. 88].

В отдалённых районах Смоленской области, куда в те годы мало проникало наблюдение епархиального центра, епископ Сергий особо выделил священника Благовещенской церкви в городе Демидове протоиерея Александра (Полканова), 1881 года рождения. Начавший свою священническую службу ещё до революции после окончания духовной семинарии в Минске, он многие десятилетия посвятил служению на Смоленщине [8]. В годы оккупации отец Александр стал известен как один из непокорных оккупантам священников. После того, как он публично призывал молиться за «дарование победы православному воинству и полководцу его Иосифу», оккупанты приговорили его к смертной казни через повешение. Однако реализовать это им не удалось - священника-патриота спасли партизаны [3, с. 269]. Когда стала налаживаться мирная жизнь, приход в Демидове ежемесячно собирал на восстановление народного хозяйства по 300-500 рублей.

Не менее интересна история священника церкви Михаила Архангела в селе Зарубинки Смоленского района протоиерея Владимира Антоновича Никоновича. Родившийся в 1878 (по другим данным, в 1877) году, он окончил духовное училище и духовную семинарию в Витебске. Вплоть до революции отец Владимир был военным священником. Начинал он псаломщиком в Тюсьбюкской военно-местной церкви в Царстве Финляндском - в ту пору провинции Российской империи. В 1905 году рукоположен в иереи, после чего был полковым священником во многих частях со славной боевой историей - В 30-м Полтавском, 31-м Алексопольском, 109-м Волжском пехотных полках. Принимал участие в боях Первой мировой войны, за мужество, проявленное под огнём неприятеля был удостоен золотого наперсного креста на георгиевской ленте - редкой и уважаемой не только среди духовенства, но и среди военных награды, учреждённой ещё Павлом I, и за всё время боёв 1914-1917 годов вручённой всего 248 раз[2].

Но пришли другие времена, и военные священники стали никому не нужны, да и сама профессия священнослужителя стала весьма опасной. Отец Владимир поселился на Псковщине, где служил сначала в Борисоглебской церкви села Сонно Себежского уезда, а затем в Успенской церкви села Кисели того же уезда. Первый раз он подвергся репрессиям ещё в 1920 году, когда в разгар Гражданской войны его в административном по- рядке выслали из прифронтовой полосы. В 1931 году он был арестован органами ОГПУ по делу так называемой «контрреволюционной церковно-монархической организации «УХД» епископа Тихона (Рождественского)». 12 ноября 1931 года Особое Совещание при Коллегии ОГПУ приговорило его к 3 годам лишения свободы [9, с. 116118, 147, 326]. С 1940 года отец Владимир жил на Смоленщине. В годы оккупации он служил священником в селе Зарубенки и в церкви села Сож Смоленского района. Ему удалось добиться крупных патриотических сборов - от 300 до 1000 руб. ежемесячно - а иногда и натурой, что в разорённой войной деревне было редкостью [11, л. 89].

Однако власти не поддержали представление в отношении Никоновича. Возможно, роль сыграли служба в старой армии и царский орден, возможно, судимость по политической статье, возможно, и то, и другое. В 1947 году Решение о награждении смоленских священнослужителей вышло без его имени. А в 1949 году отец Владимир и вовсе вновь был арестован органами МГБ СССР. Из 10 лет, к которым его приговорили, он отсидел 7, после чего был освобождён [4]. Ещё год спустя священника не стало, похоронен он на кладбище села Зарубенки [7].

В отличие от остальных кандидатов священник церкви из города Гжатска (ныне - Гагарин Смоленской области) Виктор (Никитский) был ещё довольно молодым человеком. Родился он в 1906 году. С началом Великой Отечественной войны его призвали на службу в Красную Армию и направили на фронт. В боях Никитский попал в немецкий плен, откуда был освобождён в 1942 году. Церковная служба его началась в оккупированном Рославле под руководством уже упоминавшегося выше благочинного В.М. Корицкого. После освобождения отец Виктор был переведён сначала в город Гжатск. Патриотические сборы у него выражались в суммах 200-300 рублей ежемесячно. В 1946 году отца Виктора наградили медалью «За Победу над Германией» как участника боевых действий, но, к сожалению, власти не сочли его достойным второй главной военной медали, хотя случаи, когда ветераны войны одновременно признавались и тружениками тыла, бывали неоднократно. Несколькими годами позже он будет переведён в Сычёвку, где организует строительство нового храма взамен разрушенного, и ещё много лет прослужит в нём, уйдя из жизни в 1983 году [10, с. 12].

Последним из представленных к награждению медалью «За доблестный труд в Великой Отечественной войне 1941-1945 гг.» был священник церкви Успения Пресвятой Богородицы в селе Монастырщине отец Илларион (Кузьменко). Как и многие другие, он занял этот пост в годы оккупации, и после освобождения продолжил служение. Добился значительных пожертвований на патриотические цели, собирая от 200 до 1500 рублей в месяц, а также натурой [11, л. 89]. 
Интересно, что признание заслуг священнослужителей происходило даже при понимании того, что добро на возобновление богослужений ими дали оккупационные власти, надеясь таким образом заслужить к себе лояльность духовенства, на протяжении многих предвоенных лет подвергавшегося гонениям со стороны Советской власти, а также местного населения. И тем не менее, поставить под свой контроль, использовать в своих интересах церковь на Смоленщине им так и не удалось.

Документ под названием «Список служителей религиозного культа, представляемых к награде за патриотическую деятельность в период Отечественной войны 1941-1945 гг.» был направлен уполномоченному Совета по делам Русской Православной Церкви при Совете Министров СССР по Смоленской области Никите Лаврентьевичу Митину. Ветеран партии, партизан Великой Отечественной войны, кавалер ордена Трудового Красного Знамени и Большой серебряной медали ВСXВ, он был назначен на эту должность в 1944 году и работал вплоть до своего выхода на пенсию в июле 1951 года. Из представленного списка Митин вычеркнул три кандидатуры - протоиерея Всеволода Михайловича Корицкого, протоиерея Владимира Антоновича Никоновича и священника Виктора Никитского, но при этом добавил самого епископа Сергия. По существовавшему порядку представления к наградам сам епископ не мог писать на себя представления, и осуществил представление именно Митин, как будто бы являлся его непосредственным начальником, хотя к тому времени уже почти 30 лет как церковь была отделена от государства [11, л. 87].

Епископ Сергий родился в 1883 году в СанктПетербурге. Потомственный священник, он окончил духовную семинарию и долгое время служил в сельских церквях Петербургской (Петроградской, Ленинградской) епархий. В годы Великой Отечественной войны находился в эвакуации, трудился в библиотеке Иркутского государственного университета. В июле 1944 года патриарх вызвал его в Москву, и 19 ноября того же года он получил назначение епископом Смоленской и Дорогобужской епархии. На одиннадцать лет его служения в Смоленске пришлось возрождение церковной жизни, были восстановлены и открыты некоторые храмы, несмотря на противодействие властей. Епископ Сергий внёс огромный вклад в налаживание сборов денежных средств и натуральных ценностей в Фонд обороны. Уже за первый год его работы верующими было собрано около полумиллиона рублей, которые пошли на оказание помощи детям фронтовиков, на строительство танковой колонны «Димитрий Донской», на постройку самолётов. Собранные продукты - а одних яиц за год было собрано около 8,5 тысяч - шли в госпитали, санитарные поезда, Комитету Красного Креста и детские дома [1, с. 153-160].

Как сообщил «Журнал Московской патриархии», 15 марта 1947 года состоялось уникальное для Советской Смоленщины событие - в здании облисполкома прошла торжественная церемония вручения медалей «За доблестный труд в Великой Отечественной войне 19411945 гг.» пяти священнослужителям. Представители власти поздравили награждённых, пожелали им развития плодотворной деятельности на благо Родины [5, с. 76]. Однако акт о вручении медалей был подписан председателем облисполкома А.Н. Кидиным лишь 8 апреля 1945 года. В соответствии с ним, епископ Сергий получил медаль с удостоверением № 0238996, а протоиерей Николай Валюжанич - № 0238997[11, л. 173]. Остальные акты вручения обнаружить ни в фондах областных организаций тех лет, ни в районных организациях пока не удалось.

Различные источники сообщают, что примерно в то же время в других регионах Советского Союза прошли подобные церемонии. Так даже богоборчески настроенная Советская власть официально признала ценность помощи Русской Православной Церкви в годы Великой Отечественной войны, её нежелание отчуждаться от своего народа в один из самых трудных периодов его истории. Пускай в общей массе почти 60 тысяч тружеников тыла Смоленщины эти 5 человек заметны не сразу, но свой достойный след в истории они оставили. К большому сожалению, 3 остальных кандидатов так и не получили свои медали, хотя, если судить по описанию заслуг, были вполне достойны их - но такое уж тогда было время.

\section{ЛИТЕРАТУРА}

1. Амельченков В.Л. Смоленская епархия в годы Великой Отечественной войны. - Смоленск: Свиток, 2006.

2. Военный орден Святого Великомученика и Победоносца Георгия. Именные списки 1769-1920. Библиографический справочник. Отв. сост. Шабанов В.М. - М.: Русский мир, 2004.

3. Ермолов И.Г. Под знамёнами Гитлера. Советские граждане в союзе с нацистами на оккупированных территориях РСФСР в 1941-1944 гг. - М.: Вече, 2013.

4. Зарубенки (Большие Зарубенки, Зарубинка). [Электронный ресурс] // Сайт Николаевского собора. URL: http://www.nikolaevskii-sobor.ru/kniga. php?page=zarubenki-porechskogo-uezda (дата обращения: 18.09.2021).

5. Из Смоленской епархии. // Журнал Московской патриархии. - № 7 - 1947.

6. Клирики Смоленской епархии в годы Великой Отечественной войны: протоиерей Всеволод Корицкий (1864-1954). [Электронный ресурс] // Сайт Смолен- 
ской митрополии Русской Православной Церкви. URL: http://smoleparh.ru/publikatcii/2015/03/kliriki-smolenskoy-eparhii-v-godyi-velikoy-otechestvennoyvoynyi-protoierey-vsevolod-koritskiy/ (дата обращения: 18.09.2021).

7. Никонович Владимир Антонович. [Электронный ресурс] // Электронная база данных «Новомученики, исповедники, за Христа пострадавшие в годы гонений на Русскую Православную Церковь в XX в.» URL: http://www.pstbi.ccas.ru/bin/db.exe/ans/nm/?TYZCF2JMTdG6XbuBe8eifOuWeCQUUeiUd8WgeC*UU 8rWfeqiceXb** (дата обращения: 18.09.2021).

8. Полканов Александр Николаевич. [Электронный ресурс] // Электронная база данных «Духовенство Русской Православной Церкви в XX веке». URL: https://pravoslavnoe-duhovenstvo.ru/person/10411/ (дата обращения: 18.09.2021).

9. Псковский синодик пострадавших за веру Христову в годину гонений священнослужителей, монашествующих и мирян Псковской епархии XX столетия. - М. - Псков: Духовное преображение, 2005.

10. Храм Святителя Николая. // Вяземские епархиальные ведомости. - № 11 - 2016.

11. ГАСО (Государственный архив Смоленской области). Ф. 2361 (Исполнительный комитет Смоленского областного Совета депутатов трудящихся). Оп. 7.Д. 6.

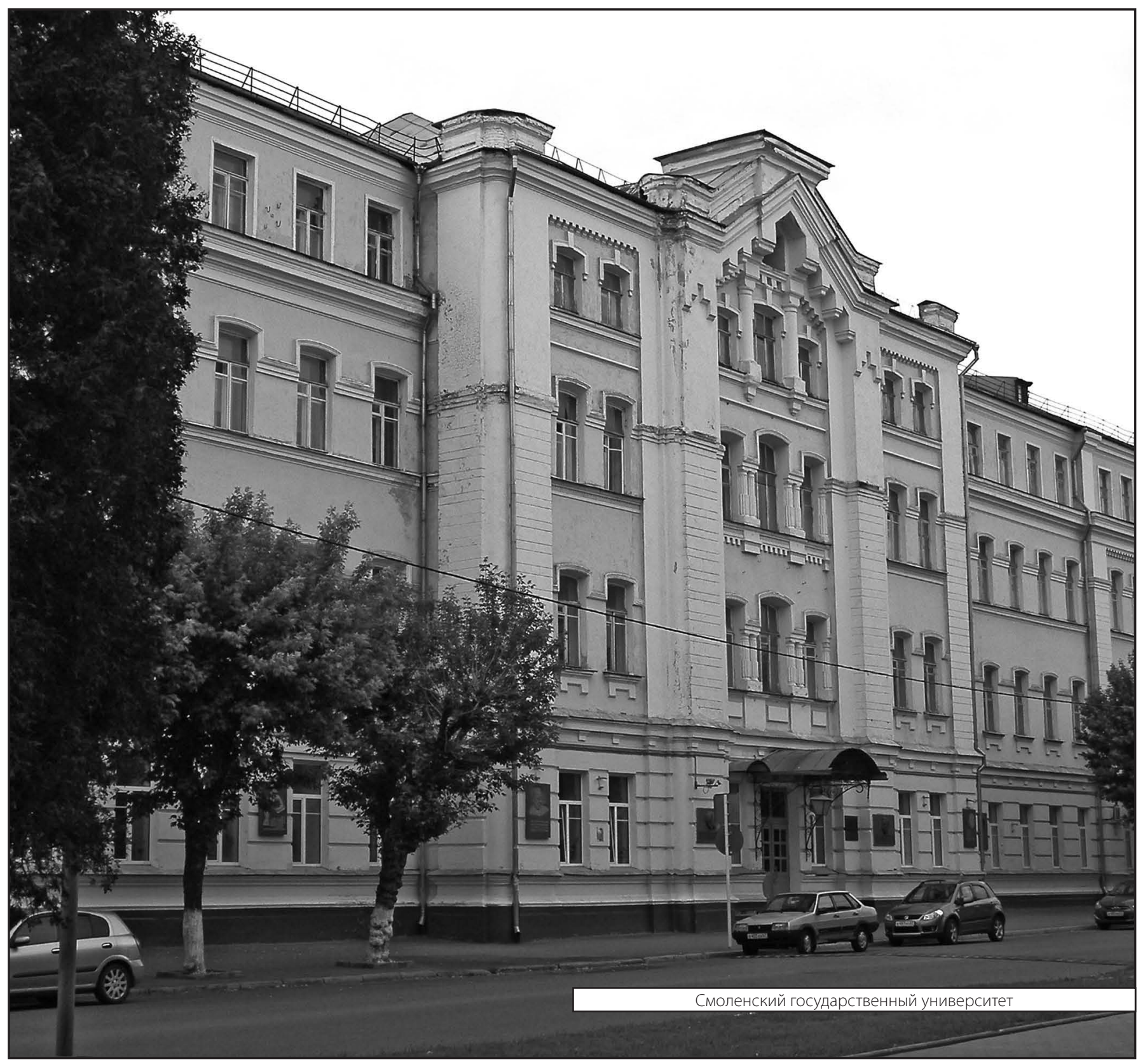

